\title{
The lake Albano: bathymetry and level changes
}

\author{
Marco Anzidei ${ }^{1,2 *}$ and Alessandra Esposito \\ ${ }^{1}$ Istituto Nazionale di Geofisica e Vulcanologia, \\ Via di Vigna Murata 605, 00143 Rome, Italy \\ ${ }^{2}$ Università della Calabria, Dipartimento di Fisica \\ Via Pietro Bucci Arcavacata di Rende, 87030 Cosenza, Italy \\ *corresponding author (marco.anzidei@ingv.it)
}

Accepted for publication on

FuniCIELLO, R. \& GiORDANO, G. (eds)

The Colli Albani Volcano.

Special Publication of IAVCEI,

3. The Geological Society, London.

Roma, December 20, 2009 


\title{
The lake Albano: bathymetry and level changes
}

\author{
Marco Anzidei ${ }^{1,2} *$ and Alessandra Esposito \\ ${ }^{1}$ Istituto Nazionale di Geofisica e Vulcanologia, \\ Via di Vigna Murata 605, 00143 Rome, Italy \\ ${ }^{2}$ Università della Calabria, Dipartimento di Fisica \\ Via Pietro Bucci Arcavacata di Rende, 87030 Cosenza, Italy \\ *corresponding author (marco.anzidei@ingv.it) \\ number of words of text:3615 \\ number of references:55 \\ number of figures: 7 \\ Running title: The Lake Albano
}

\begin{abstract}
The Lake Albano is situated in the Colli Albani volcanic district, about $20 \mathrm{~km} \mathrm{SE}$ from the city centre of Rome. It is $287 \mathrm{~m}$ above sea level and is the deepest among the volcanic crater lakes of Italy, being presently $167 \mathrm{~m}$ deep. It is $3.5 \mathrm{~km}$ long and $2.3 \mathrm{~km}$ wide with an area of about $6 \mathrm{~km}^{2}$. The crater has a long history, which starts with the formation of the Albano crater $\sim 70$ ka B.P., and shows evidence of human settlements since pre-historical times. Geological evidence indicates that a catastrophic overflow of the lake occurred in 396 B.C.E. due to a rapid increase of the water level. This phenomenon persuaded the Romans to excavate an artificial outlet though the crater wall to control the lake level. The lake is thought to be hazardous for the surroundings human settlements and the city of Rome, high resolution multibeam bathymetry of the of Lake Albano was performed for the Italian Dipartimento della Protezione Civile, in order to evaluate the potential for $\mathrm{CO}_{2}$ storage and eruption from the lake. The shape of the crater floor was mapped in 2-D and 3-D. Here, we show the main submerged morphological features and a brief history of the lake level changes, which still affect this basin today.
\end{abstract}

\section{End of Abstract}

The composite Via dei Laghi edifice (Giordano et al. 2010, this volume), consists of several monogenetic and polygenetic phreatomagmatic craters located along the northern and the western 
slopes of the Colli Albani volcanic complex. The polygenetic Albano maar (Fig.1a,b) is the youngest of these craters (De Rita et al.1987; De Rita et al.1988; Trigila 1995; Villa et al.1999; Funiciello et al. 2003; Marra et al. 2003; Giordano et al. 2006; Freda et al. 2006). The oldest deposits of the Albano maar are dated at $69 \pm 1$ ka (Freda et al. 2006). The age of the youngest Colli Albano eruption is still debated, and some researchers proposed Holocenic to Roman age for volcanic (Andretta \& Voltaggio 1988) and phreatic activity (Funiciello et al. 2003). During the last two or three centuries, several historical documents mentioned the Albano lake and discussed its volcanic origin (Gmelin 1814; Guattani 1805; Nibbi 1819; Brocchi 1820; Rufini 1861, Ponzi 1875; Struver 1876; Portis 1893; Washington 1920). Among them, Ponzi (1875), was the first who described the geological traces left on the ground by a possible outflow of Lake Albano, which likely occurred in connection with the end of the volcanic activity. Recent stratigraphic studies (Funiciello et al. 2003) recognised a lahar succession produced by repeated lake overflows towards Rome (Tavolato formation of the Ciampino Plain, in Fig. 1a), whose youngest deposit is dated at 5.8 \pm 0.1 ka (De Benedetti et al. 2008).

Lake level oscillations have been suggested since Holocene, and inferred by the presence of sedimentary hiatuses in the lake sediments, as well as changes in $\mathrm{CaCO}_{3}$ deposition rate and isotopic composition in the lake sediments (Guilizzoni \& Oldfield, 1996; Funiciello et al. 2003; Marra \& Karner 2005; Anzidei et al. 2008). First reports on the lake level changes, arise from the historical writer Dionigi from Alicarnasso, who lived in Rome between 60 and 7 B.C.E.. He described in his book Antiquitates Romanae XII, 9,3, the catastrophic effects of the outflow of Lake Albano. His story was later reported by other Latin (Plutarco, Tito Livio) and modern authors (Gmelin 1814; Nibbi 1819; Brocchi 1820; Rufini 1861, Ponzi 1875; Struver 1876; Portis 1893; Washington 1920, Funiciello et al. 2003), who reported on a sudden rise of the lake level, which overflowed during the Roman war against the city of Veio, between July 23th and August 24th 398 B.C.E. (one year after the date shown by Tito Livius in Historia Romae, book V, 15:4-7), they also noted that it occurred during a climatic dry period. It is remarkable that, according to the available descriptions, the lake level rose so rapidly up to the crater rim without any water bubbling or important surface movements. Thus, the water flowed down the crater slope, and across the land toward the Tyrrhenian Sea. After this catastrophic event, the Romans sent delegates to the Oracle of Delphi to ask for explanations.. The oracle instructed that they build a drainage tunnel through the crater wall to keep the lake to a safe level (293 m a.s.l.). The tunnel drain (RT in Fig. 2b, 7e,f) hosts a fixed limnographic station which was used to indicate changes in the lake level but is now out of use as the lake has fallen well below the tunnel opening (Fig.7g). The historical chronicles provide 
further, albeit mythical, information indicating lake level changes, they infer that the large oscillations were mainly a result of god's revenge.

The basin form was still unknown until modern times, when some bathymetric mapping of the lake floor was attempted (Fig.2a). The first measurements were performed through simple depthsoundings and some isobaths appeared in the 1:25,000 topographic maps edited by the Italian Istituto Geografico Militare in 1940 (maps F150 Albano and Frascati), although surveys are partially dated back to 1873. In the 1980s, direct observations of the lake made during a small submarine survey revealed perfuse benthic gas bubbling in several places and first order features of the volcanic lake floor (Caputo et al. 1986). In 1995, a more accurate map was produced under the framework of the PALICLAS project (Chondrogianni et al. 1996). This map, however, was still low resolution (data collected by single beam surveys, prone to low accuracy from imprecise optical vessel positioning, and infrequent sounding samples of the lake floor). Given the potential hazards of the lake resulting from gas exsolution (see Carapezza et al. 2010, this volume) and the lack of an accurate bathymetric map, there is an necessity to perform a very high resolution topographic study. Mapping of the lake is carried out using a very high resolution multibeam survey of the lake. This contribution largely draws and summarizes the paper by Anzidei et al. 2006 and Anzidei et al. 2008.

\section{Multibeam bathymetry (MBB)}

The first high resolution MBB study or survey of Lake Albano, was performed in November 2005, using a small vessel (6 m long) suitable to be launched and navigate in a small closed basin. The boat was equipped with ultra high resolution multibeams (MB) and survey instrumentation. Due to the depth of the lake, two different very high resolution MBs were used: the Reson Seabat 8125 ( 250 beams, $0.5^{\circ} \times 1.0^{\circ}$ sector coverage, $455 \mathrm{Khz}$ ), and the Reson Seabat 8101 (101 beams, $0.5^{\circ} \mathrm{x}$ $0.5^{\circ}$ sector coverage, $455 \mathrm{Khz}$ ), working in the depth range $0-80 \mathrm{~m}$ and $>80 \mathrm{~m}$, respectively. The bathymetric datum was fixed by measuring the lake water level through GPS measurements along the shore. The instrumental height of the zero level was referred to a WGS84 geodetic benchmark (named ALBA) located close to the lake (Fig.1a). The latter was precisely measured using GPS with respect to the GPS geodetic monument of INGR, located at Istituto Nazionale di Geofisica e Vulcanologia in Rome (INGV) (Fig.1a), which belongs to the RING National GPS network (http://ring.gm.ingv.it), and its 3-D coordinates were accurate to a few $\mathrm{mm}$ at the November 2005 epoch (Anzidei et al. 1998; Serpelloni et al. 2005). Elevation data of lake floor were thus saved in the WGS84 reference system. Positioning of the vessel during surveys (i.e. of the MB sensor), was 
accurate to a few cm using a GPS in RTK mode, after calibration lines were performed after which the roll, pitch and yaw correction angles were used to correct the installation geometries. Navigation routes were performed with at least $20-30 \%$ of overlap between neighbouring sweeps, to obtain a full and detailed coverage of the lake bottom. The Reson PDS2000 software was used to control in real time the ongoing MB survey, as well as the integrity of the positioning information used for guidance of the boat.

Data analysis was performed by the Computer Aided Resource Information System - Hydrographic Information Processing System (CARIS - HIPS) PRO V5.2 software, which is specifically designed to process $\mathrm{MB}$ data under Windows $\mathrm{NT}^{\circledR}$ and is capable of managing images in a mosaic of the lake floor and producing raster and analytical maps. Low quality data were discarded (i.e. those with a non-optimal signal to noise ratio), but keeping intact signatures (i.e., those produced by gas bubbles uprising from the lake floor). Lake level corrections of the GPS/RTK data were performed. From this data, high accuracy Lake Digital Elevation Models (LDEM) were produced, using a total amount of $\sim 1.5$ million 3-D punctual data points (Latitude, Longitude and depth), that were converted in the UTM33-WGS84 coordinate system. The survey data set was analysed to reduce any positioning offset or error in the LDEM, together with the analysis of the standard deviations of the MB data. The latter show values of $10-15 \mathrm{~cm}$ in the depth range $0-20 \mathrm{~m} ; 15-30 \mathrm{~cm}$ between -20 and $-50 \mathrm{~m}$ and 30-50 cm up to the lake bottom. Additional details are reported in Anzidei et al. (2006).

Once the offsets and errors were analysed and corrected, the final LDEM was produced and made available for the morphostructural analysis and the production of contour and shaded relief maps (Fig.2b). Bathymetric data were merged with data from an aerial Lidar survey (Baiocchi et al. 2006; Baiocchi et al. 2007) performed at an altitude of $1200 \mathrm{~m}$, using an Optech ALTM 3033 laser scanner which collected data along 13 routes (30\% overlapped) and with a mean accuracy of $15 \mathrm{~cm}$. Continuous aircraft positioning during survey was performed through an onboard GPS system and the available GPS stations at ground control points. Point coordinates in the WGS84 reference system at the topographic surface were then provided, together with orthometric and ellipsoidal heights. Finally, the obtained Digital Terrain Model (DTM) of the whole area, which showed the complexity of the Albano crater basin, became available for geo-morphological analyses of the whole volcanic structure (Fig. 2b). 


\section{Lake floor maps and morphology}

The LDEM provides an accurate description of the lake floor morphology showing features which reflect its volcanic history as well as the repeated changes of water level. The main features of the basin can be summarized as follows:

- the ellipsoidal shape of the Lake Albano results from the coalescence of five craters (A to E in Fig.2b). Its basin is NW-SE trending, $3.5 \mathrm{~km}$ long and $2.3 \mathrm{~km}$ wide, with a surface area of about $6 \mathrm{~km}^{2}$ (Fig. 1b, 2a and 2b).

- The lake bottom shows three main flat surfaces (FS) at different depths (FS I at 0-40m, FS II at -100-125m, FS III at -160-167m) linked by two major scarps at depths of -20, 110, and -165 m (Figs. 2b and 3a). The north-western FS I at is horse-shoe shaped (Figs. 3a, 4b, 4c), and is gently sloping $\left(<5^{\circ}\right)$ toward the central sector from shoreline to $-40 \mathrm{~m}$ depth. After this there is an abrupt increase in the slope angle $\left(15^{\circ}\right)$ down to the deeper, circular FS II (Fig. 3a, 4b, 4c). FS II occurs between -100 m and -125 m depth, with a width of $750 \mathrm{~m}$ and sharply truncated by a scarp ( $18^{\circ}$ slope) that leads to the deepest circular flat platform FS III (Fig. 3a, 4b, 4c) FS III is $670 \mathrm{~m}$ in diameter, concentric to the FS II -occurring from -160 and -167m depth.

- The scarp between the FS I and II is interrupted by a horse-shoe shaped depression (634 x $600 \mathrm{~m}$ ) which is open toward the south-east, i.e. toward the depression C (Fig. 2b and $3 a, 4 b$ and $4 c)$.

- FS II shows several minor circular depressions and the most noteble of thesedepression $\mathrm{C}$ is $530 \mathrm{~m}$ in diameter (Fig. 2b). Its annular rim is at $-112 \mathrm{~m}$ and encircles a flat depression at $-115 \mathrm{~m}$ (Fig. 2b, 3a, 4b, 4c). The less defined depression D (Fig. 2b) measures 440 x $550 \mathrm{~m}$ and has an outlet on its east side.

- Several small scarps, 2-4 metres high, can be identified on FS I (Fig. 3b). More discontinuous scarps are located at -20 m, -34 m, -37 m and - 40 m. (Fig. 3a).

- The submerged flanks of the crater show several slides, landslide channels and landslide accumulations of different size and shape (Fig.4a), which often are the products of subaerial sliding morphologies (Bozzano et al. 2009). They display variable features in terms of geometry, slope angle and spatial distribution and are typically subaqueous dynamics (Hampton \& Locat 1996; McAdoo et al. 2000; Legros 2002; Locat \& Lee 2002; Canals et al. 2004; Huhnerbach et al. 2004; Bozzano et al. 2009). The most evident concave landslide scars are located along the principal scarps. The dimensions of these landforms are between 10 and $100 \mathrm{~m}$. The biggest scarps are represented by the horse-shoe shaped depression located in northern sector of the lake, between FS I 
and FS II (Figs. 3a, 4b, 4c). The landslide scars recognised along the rim of FS III (Figs. 4a, 4b, 4c) indicate peripheral and inner surface sliding morphologies. Landslide channels and chutes have been recognised along the eastern border of FS II. They have an asymmetrical radial pattern and debris deposits at their base (Fig.4a).

- Landslide debris (Fig.4a) is located in gently dipping areas $\left(0^{\circ}\right.$ to $\left.10^{\circ}\right)$ down to $100 \mathrm{~m}$ below lake level. These deposits typically have a hummock morphology and sometimes show the presence of blocks.

- The volume of the crater presently occupied by the lake is $447.5 \times 10^{6} \mathrm{~m}^{3}$. Its volume between $45 \mathrm{~m}$ (the average depth of FS I) and $125 \mathrm{~m}$ depth (the average depth of surface II), is $217.8 \times 10^{6} \mathrm{~m}^{3}$. The volume of the deepest central depression, between FS II at $125 \mathrm{~m}$ and the maximum depth (FS III at $167 \mathrm{~m}$ ), is $15.3 \times 10^{6} \mathrm{~m}^{3}$. The total crater volume calculated by combining the bathymetric data for the submerged part and the available DEM data for the subaerial portion is $\sim 895.7 \times 10^{6} \mathrm{~m}^{3}$.

- Relevant exhalative centres are presently lacking on the lake bottom, although small bubbling possibly occur that is beyond the detection limit of the MB technique.

\section{Craters}

The LDEM suggests the presence of five coalescent craters within the lake (Figs. 2b and 3a). The circular FS are likely the morphological expression of submerged craters, assuming that younger craters cut the older ones. Fig. 2b shows, from oldest to youngest, the five recognized craters (labelled A to E), all NW-SE aligned with relative age decreasing from NW to SE.

The bottom of crater A is represented by the shallowest FS I (Fig. 2b, 3a). When the direct data from drilling in crater A (Chondrogianni et al. 1996) are also considered, the flat morphology of FS I $\left(<5^{\circ}\right)$ can be related to the presence of at least $10 \mathrm{~m}$ of lacustrine stratified sediments. The steepness (about $15^{\circ}$ ) and coarse morphology of the slope between $45 \mathrm{~m}$ and $100 \mathrm{~m}$ depth suggests an infilling, below the sediments, by massive rocks, likely lithified phreatomagmatic tuffs or lava flows. Crater B is the largest one and corresponds to the ring-shaped FS II. Craters C and D are of smaller diameter and located within crater B. Crater C is encircled by a well defined rim on average 3-4 m higher than its flat bottom (Figs $2 \mathrm{~b}$ and 3a). A seismic reflection profile and core sediments sampled across crater $\mathrm{C}$ shows the shoulder wall of the crater and the presence of sub-horizontal sediment crater filling (seismic profile C-D and core ALB3, in Guilizzoni \& Oldfield, 1996). The youngest crater E corresponds to the deepest FS. 


\section{Evidence of lake level changes}

\section{a) Past and historical times}

The lake level experienced several changes in the past, which have been recorded by geological and a range of archaeological indicators (Figs.3b, 4b, 4c, 7a-g). The small scarps bordering crater A, can be interpreted as past lake shorelines (Fig. 3b). The observed scarps create the isobaths and cut the soft lacustrine sediments. Similar scarps have been already observed in other active volcanic crater lakes (e.g. at Yellowstone Lake) and are attributed to variations of the water table (Morgan et al. 2003). The four recognized levels of Albano paleo-shorelines at -20, - 34, -37 and -41 m (Fig.3b), are in agreement with a sedimentary hiatus found by Chondrogianni et al. (1996) in the sediment cores drilled within the lake. This hiatus is $7.1 \mathrm{ka}$ to $4.5 \mathrm{ka}$ old and consequently, this should be the time interval when the lake surface was at those levels. On the other hand, this is also the time interval during which a lahar-generating overflow occurred from Lake Albano (5800 yr B.P., Funiciello et al. 2003; De Benedetti et al. 2008) (Fig. 6). The occurrence of high and low standings of the lake level has been previously suggested by Andretta \& Voltaggio (1988), Funiciello et al. (2003) and Marra \& Karner (2005). The lake level must have been slightly lower than present during Middle Bronze age, when a peri-lacustrine village was settled along the northern shore of the lake (about 3600 yr B.P., Villaggio delle Macine, in Carandini, 1997; Figs. 2b, 7c). Despite the recent water drawdown, this village is still partly submerged (-2 m in Fig. 6). Between 100 and 200 C.E. the lake was about $2 \mathrm{~m}$ above its present level, as evidenced by the remnants of a small harbour of the Roman age (RH in Fig. 2b), whose basin is located in the northern side of the lake. Nowadays, the harbour is completely drained (Fig. 7d).

In conclusion, it seems that one set of evidence indicates that in the last 7.1 ka the lake level has changed from $-41 \mathrm{~m}$ to $+6 \mathrm{~m}$ with respect to the level measured in November 2005 (Fig. 6), corresponding to $287 \mathrm{~m}$ a.s.l.. However, another set of evidence, based on existing geological and historical evidence (Funiciello et al.2003 and references therein) indicates that within the time span 5.8 - $2.4 \mathrm{ka}$, lake level increases occurred, that caused an overflow from the crater in the direction of Rome, at least on two occasions. These dramatic outflows occurred from the lowest elevation point of the crater rim, which is at $367.5 \mathrm{~m}$ a.s.l., i.e. $80.5 \mathrm{~m}$ higher than the present lake level (Figs. 5, 6). This lake level rise is far larger than any possible variation related to climatic events during the Holocene, suggesting endogenous causes. Lake level changes may occur in response to episodic uplift and subsidence due to inflation and deflation of the central part of the volcano, as recently 
observed by instrumental data at Albano (Amato \& Chiarabba 1995; Anzidei et al. 1998; Salvi et al. 2004; Riguzzi et al. 2009). Furthermore, cycles of self-sealing versus seismic opening of the system may account for groundwater table oscillations by rock permeability variations. Tuccimei et al. (2006) recently demonstrated that at Colli Albani there are cycles of calcite precipitation in fractures, and that these are likely interrupted when earthquakes favour the increase of $\mathrm{CO}_{2}$-rich deep fluid uprising. Calcite precipitation can therefore be responsible for self-sealing processes reducing permeability and causing a progressive increase in gas pore pressure at depth. An alternative explanation for the lahar-generating overflows may be the repeated occurrence of Nyostype events (Barberi et al. 1989; Rice 2000). These can be induced by lake rollovers during times in which deep water is rich (nearly saturated) in dissolved $\mathrm{CO}_{2}$, whose decompression would produce its sudden release, generating water-gas jet and large waves capable to overpass the crater rim. The rollovers may be also triggered by injection of hot fluids at the lake bottom (Funiciello et al. 2003), as well as by earthquake shaking or even by landslides (Bozzano et al. 2009).

\section{b) Modern times}

The first official measurements of the lake depth, appeared in the topographic maps of the Italian Istituto Geografico Militare, dated back to 1940, although surveys based on observations were started at the end of 1800 (Fig.2a). Older maps show the lake level elevation to be $293 \mathrm{~m}$ a.s.l., giving a difference of $6 \mathrm{~m}$ with respect to the 2005 measurements. In 1984, Caputo et al. (1986) the depth of the lake was $173 \mathrm{~m}$, again showing a $6 \mathrm{~m}$ difference to measure made in 2005. Measurements indicate that there has been a continuous lowering of the lake level since 1970,also shown by observational data (Figs. 6, 7a-g), with a progressive acceleration during the last 15 years (Capelli et al. 2000; Capelli \& Mazza 2005; Mazza \& Capelli 2010; Riguzzi et al. 2008). The data show that the lake level was relatively stable in the period between 1940 and 1960 followed by a lake level drawdown at a mean annual rate of $8.8 \mathrm{~cm}$ during 1960-2005 and at $20 \mathrm{~cm}$ during 19901997 (Fig. 6). Our results are in agreement with Capelli \& Mazza (2005) and Riguzzi et al. (2008), who estimate a lowering rate of 22 and $27 \mathrm{~cm} / \mathrm{yr}$, respectively. The cause of the lake level lowering is still debated, but there is a general agreement among the hydrogeologists that it can be largely attributed to excessive and increasing ground water withdrawal from private and industrial wells (Capelli \& Mazza, 2005). However, other causes can be invoked, such as shallow seismicity (Bianchi et al. 2008; Chiarabba et al. 2010) or ground uplift (Amato \& Chiarabba 1995; Riguzzi et al. 2009). Recent seismicity and seismic swarms aligned along a NW-SE striking structure that crosses the centre of Lake Albano and the other craters of the Colli Albano volcano occurred during 1987-1990 (Amato et al. 1994, Bianchi et al. 2008) and were followed by significant lake drawdown 
in 1990. It was suggested that an increased permeability of the lake basin was produced by these endogenous processes.

\section{Conclusions}

The first very high resolution MB survey provided a detailed 3-D morpho-bathymetric map of the Lake Albano at $<1 \mathrm{~m}$ average pixel resolution. Currently, these data, merged with Lidar data for the subaerial part of the Albano crater, are improving the geological, geomorphological, volcanological, geochemical and geophysical monitoring of this active volcanic area. The revealed lake floor shows the past episodes of its history that coincided with the geological and volcanological evolution of the area. Surface features due to volcanic activity, recent surface and lake level changes and sliding or rock fall events, are clearly evident from the 2-D and 3-D maps (Figs. 2b, 3a, 3b, 4a, b, c). The issues related with the occurrence of slides and gas exhalative points (the latter reported by Funiciello et al. (2002), but not revealed by MB surveys), are relevant for scientific discussion and hazard assessment of the Lake Albano and its bathymetry support new hypothesis and questions on its recent evolution, even until historical and modern times, thus suggesting further investigation through the integration of geological and geophysical research. Although the central deep crater is a potential trap for $\mathrm{CO}_{2}$ accumulation that could prove perilous if suddenly released, as already occurred at lake Nyos (Rice 2000), Anzidei et al. (2008), concluded that the present day $\mathrm{CO}_{2}$ concentration, which still remains the highest among the Italian crater lakes, is not critical enough to induce a water rollover with dangerous consequences of a gas or hot fluids release from the deepest part of the lake basin. Currently, the quantity of $\mathrm{CO}_{2}$ dissolved in the lake has values too low to generate Nyos-type events (Carapezza et al. 2010a,b, this volume). Among the different sources of hazard, slides from the subaerial and submerged inner flank of the crater, must be taken into account as their occurrence would be capable to induce fast and high lake waves, potentially dangerous for humans and the environment. Hence, the occurrence of such events in Lake Albano should not be excluded given the continuing seismicity of the area, and the steep slopes of the inner side of the crater facing the lake (Anzidei et al. 2006; Bozzano et al. 2009). The area is also affected by ground uplift (Amato \& Chiarabba 1995; Riguzzi et al. 2009) and by large scale release of gas with geochemical evidence of a magmatic component (Carapezza \& Tarchini 2007). This evidence and the occurrence of the Holocene lahars from Lake Albano (Funiciello et al. 2003) indicate that this structure has to be considered still active and likely connected at depth with an actively degassing magma chamber. Further surveys, such as seismic soundings and sub-bottom profiles, will provide new data on the still unknown structural features of the lake floor. Therefore the Colli Albani 
volcano deserves the same monitoring and hazard assessment effort of any active volcano near an urban area.

\section{Acknowledgements}

Surveys were performed under the Colli Albani Project V-3 funded by the Italian Dipartimento della Protezione Civile. We wish to tank Maria Luisa Carapezza, Luca Pizzino, Piergiorgio Scarlato and Guido Ventura of INGV and Franco Barberi, Renato Funiciello and Guido Giordano of the Geological Dept. of the University of Roma 3 for the fruitful discussion on the results. Vincenzo Sepe of INGV who contributed to levelling surveys. Enrico Tonali, Michele De Lauretis and Marcella Iacovelli, of the Italian Rowing Federation of the Italian National Olympic Committee, who provided valuable documents on the recent lake history. G. Heiken and N. Ellwood are acknowledged for their thoughtful reviews.

\section{References}

Amato, A., ChiarabBa, C. 1995. Recent uplift of the Alban Hills Volcano (Italy): evidence for magmatic inflation? Geophysical Research Letters, 22, 1985-1988.

Amato, A., ChiarabBa, C., Cocco, M., Di Bona, M., Selvaggi, G. 1994. The 1989-1990 seismic swarm in the Alban Hills volcanic area, central Italy. Journal of Volcanology and Geothermal Research, 61, 225-237.

Andretta, D. Voltaggio M. 1988. La cronologia recente del vulcanismo dei Colli Albani, Le Scienze, 41, 243, 26-36.

Anzidei, M., Carapezza, M.L., Esposito, A., Giordano, G., Lelli, M., TARChini, L. 2008. The Albano Maar Lake high resolution bathymetry and dissolved $\mathrm{CO}_{2}$ budget (Colli Albani volcano, Italy): Constrains to hazard evaluation. Journal of Volcanology and Geothermal Research, 171, 258-268.

AnZidei, M., Esposito, A. De Giosa, F. 2006. The dark side of the Albano crater lake. Annals of Geophysics, 49, 1275-1287.

Anzidei, M., Baldi, P., Casula, G., Galvani, A., Riguzzi, F. Zanutta, A. 1998. Evidence of active crustal deformation of the Colli Albani volcanic area (central Italy) by GPS surveys. Journal of Volcanology and Geothermal Research, 80, 55-65. 
Baiocchi, V., Anzidei, M., Esposito, A., Fabiani, U., Pietrantonio, G. Riguzzi, F. 2006. Integrazione di rilievi batimetrici e laser scanner da aereo nell'area dei Colli Albani. Atti della X Conferenza Nazionale dell'ASITA, Bolzano 14-17 Novembre 2006.

Baiocchi, V., Anzidei, M., Esposito, A., Fabiani, U., Pietrantonio, G. Riguzzi, F. 2007. Integrer bathymetrie et Lidar. Geomatique Export, 55, 32-35.

Bianchi, I., Piana Agostinetti, N., De Gori, P. ChiarabBa, C. 2008. Deep structure of the Colli Albani volcanic district (central Italy) from receiver functions analysis. Journal Geophysical Research, 113, B09313, doi:10.1029/2007JB005548.

Bozzano, F., Mazzanti, P., Anzidei, M., Esposito, C., Floris, M., Bianchi FAsani, G. Esposito, A. 2009. Slope dynamics of Lake Albano (Rome, Italy): insights from high resolution bathymetry. Earth Surface Processes and Landforms, 34. 1469-1486. DOI: 10.1002/esp.1832.

Brocchi, G. 1820. Dello stato fisico del suolo di Roma. Stamperia De Romanis, Roma. http://books.google.it/books

Capelli, G., Mazza, R., Giordano, G., Cecili, A., De Rita, D., Salvati, D. 2000. The Colli Albani Volcano (Rome, Italy): equilibrium breakdown of a hydrogeological unit as a results of unplanned and uncounted over exploitation. Hydrogeologique, 4, 63-70.

CAPElli, G., MazzA, R., 2005. Water criticality in the Colli Albani (Rome, Italy). Giornale di Geologia. Applicata, 1, 261-271, doi: 10.1474/GGA.2005-01.0-26.0026.

Caputo, C., Ciccacci, S., D’Alessandro, L., Davoli, L., Fredi, P., La Monica, G.B., Lupia Palmieri, E., Pugliese, E., RAfFi, R. 1986. In Progetto «Lago Albano». Indagini climatiche, geomorfologiche e sedimentologiche, Provincia di Roma, 1-14.

CARANDini, A., 1997. La nascita di Roma: dei, Lari, eroi e uomini all'alba di una civiltà, Einaudi, Torino, 766 pp.

Carapezza, M.L., Lelli, M. TARChini, L. 2010. Geochemestry of the Albano Crater laKe. In: Funiciello, R. \& Giordano, G. (EDS) The Colli Albani Volcano. Special Publication of IAVCEI, 3. The Geological Society, London, 000-000.

Carapezza, M.L., Barberi, F., TARChini, L., Ranaldi, M., Ricci, T. 2010. Volcanic hazard of Colli Albani. In: Funiciello, R. \& Giordano, G. (eds) The Colli Albani Volcano. Special Publication of IAVCEI, 3. The Geological Society, London, 000-000.

CARAPEZZA, M. L., TARCHini L. 2007.Magmatic degassing of the Alban Hills volcano (Rome, Italy): geochemical evidence from accidental gas emission from shallow pressurized aquifers. Journal of Volcanology and Geothermal Research Submitted

CARIS-HIPS (Hydrographic Information Processing System) and SIPS professional v.5.2 software User Guide: (2002): MA-HIPS-UG-02-02 www.caris.com. 264 Rookwood av. Fredericton, Canada.

Chiarabba, C., Giordano, G., Mattei, M., Funiciello, R. 2010. The 3D structure of the Colli Albano volcano. In: Funiciello, R. \& Giordano, G. (eds) The Colli Albani Volcano. Special Publication of IAVCEI, 3. The Geological Society, London, 000-000. 
Chondrogianni, C., Ariztegui, D., Niessen, F., Ohlendorf, C., Lister, G. 1996. Late Pleistocene and Holocene sedimentation in Lake Albano and Lake Nemi (central Italy). Guilizzoni G. and Oldfield F., Guest Eds. Paleoenvironmental Analysis of Italian Crater Lake and Adriatic sediments. Memorie Istituto Italiano Idrobiologia, 55, 23-38.

De Benedetti, A.A., Funiciello, R., Giordano,G., Diano, G., Caprilli, E., Paterne, M. 2008. Volcanology, history and myths of the Lake Albano maar (Colli Albani volcano, Italy) Journal of Volcanology and Geothermal Research, 176, 387-406.

De Rita, D., Funiciello, R., Pantosti, D. 1987. Dynamics and evolution of the Albano crater, south of Roma, Proceeding. IAVCEI International. Conference, Kagoshima, 502-505.

De Rita, D., Funiciello, R., Parotto, M. 1988. Carta Geologica del Complesso vulcanico dei Colli Albani (Geological map of the Colli Albani volcanic complex), scale 1:50,000, Consiglio Nazionale delle Ricerche.

Freda, C., Gaeta, M., Karner, D., Marra, F., Renne, P.R., Taddeucci, J., Scarlato, P., Christensen, J. N., DALlAi, L. 2006. Eruptive history and petrologic evolution of the Albano multiple maar (Alban Hills, Central Italy). Bulletin of Volcanology, 68, 6, 567-591.

Funiciello, R., Giordano, G., De RitA, D. 2003. The Albano maar lake (Colli Albani Volcano, Italy): recent volcanic activity and evidence of pre-Roman Age catastrophic lahar events, Journal of Volcanology and Geothermal Research, 123, 43-61.

GIORDANO, G. THE CARG TEAM 2010. Stratigraphy and volcano-tectonic structures of the Colli Albani volcanic field. In Funiciello, R. \& Giordano, G. (eds) The Colli Albani Volcano. Special Publication of IAVCEI, 3. The Geological Society, London, 000-000.

GMELIN L. 1814. Observationes oryctognosticae et chemicae de Hauyna et de quibusdam fossilibus quae cum concreta inveniuntur; praemissis animadversionibus geologicis de montibus Latiis Veteris. Heidelbergae, 53 pp.

Guattani G.A. 1805. Roma descritta ed illustrate. Tomo I, Stamperia Pagliarini, Roma. http://books.google.it/books

Guilizzoni, G., Oldfield, F. (Guest Eds.) 1996. Paleoenvironmental Analysis of Italian Crater Lake and Adriatic sediments. The PALICLAS Project: synthesis and overview, Memorie Istituto Italiano Idrobiologia, 55, 329-357.

HAMPtON, M.A. LoCAT, J., 1996. Submarine landslides. Review in Geophysics, 34, 1, 33-59.

LOCAT, J., LEe, H.J. 2002. Submarine landslides: advances and challenges. Canadian Geotechnical. Journal, 39, 193-212.

Marra, F., Freda, C., Scarlato, P., Taddeucci, J., Karner, D.B., Renne, P.R., Gaeta, M., Palladino, D.M., Trigila, R., Cavarretta, G. 2003. Post-caldera activity in the Albani Hills volcanic district (Italy): ${ }^{40} \mathrm{Ar} /{ }^{39} \mathrm{Ar}$ geochronology and insights into magma evolution. Bulletin of Volcanology, 65, 227-247, doi: 10.1007/s00445-002-0255-9.

MARRA, F., KARNER, D.B. 2005. The Albano maar (Alban Hills volcanic district, Italy): active or dormant volcano? Il Quaternario, 18-2, 173-185. 
Martini, M., Giannini, L., Prati, F., Tassi, F., Capaccioni, B., Iozzelli, P. 1994. Chemical characters of crater lakes in the Azores and Italy: the anomaly of Lake Albano. Geochemical Journal, 28, 173-184.

MazzA, R., Capelli, G. 2010. Hydrogeology of the Colli Albani unit. In: Funiciello, R. \& Giordano, G. (eds) The Colli Albani Volcano. Special Publication of IAVCEI, 3. The Geological Society, London, 000-000.

McAdoo, B.G., Pratson, L.F., Orange D.L. 2000. Submarine landslide geomorphology, US continental slope. Marine Geology, 169, 103-136.

Morgan, L. A., Shanks, W.C., Lovalvo, D. A., Johnson, S.Y., Stephenson, W. J., Pierce, K. L., Harlan, S.S., Finn, C.A., Lee, G., Webring, M., Schulze, B., Duhn, J., Sweeney, R., BALISTRIERI, L. 2003. Exploration and discovery in Yellowstone Lake: results from highresolution sonar imaging, seismic reflection profiling, and submersible studies. Journal of Volcanology and Geothermal Research, 122, 221-242.

NiBBI, A. 1819. Viaggio antiquario nè contorni di Roma. Presso Vincenzo Poggioli Stampatore Camerale, Roma, 1819. http://books.google.it/books

PonZI, G. 1875. Storia dei vulcani laziali, Memorie Fisiche Regia Accademia Nazionale dei Lincei, II, vol.I, 26-42.

PORTIS, A. 1893. Osservazioni sopra la formazione stata chiamata Conglomerato del Tavolato. Storia fisica del bacino di Roma, 259-293.

RESON B.V. Denmark PDS 2000 hydrographic surveys data acquisition and processing software.

RICE, A., 2000. Rollover in volcanic crater lakes: a possible cause for Lake Nyos type disaster. Journal of Volcanology and Geothermal Research, 97, 233-239.

Riguzzi, F., Pietrantonio, G., Devoti, R., Atzori, S., Anzidei, M. 2009. Volcanic unrest of the Colli Albani (central Italy) detected by GPS monitoring test. Physics of the Earth and Planetary Interiors in press, doi/10.1016/j.pepi.2009.07.012

Riguzzi, F., Pietrantonio, G., Baiocchi, V., Mazzoni, A. 2008. Water level and volume estimations of the Albano and Nemi lakes (central Italy). Annals of Geophysics, 51, 563-573.

RufinI, A. 1861. Guida di Roma e i suoi dintorni. Dalla Tipografia Forense, Roma.

RUFINI, 1861, http://books.google.it/books

Salvi, S., Atzori, S., Tolomei, C., Allievi, J., Ferretti, A., Prati, C., Rocca, F., Stramondo, S. AND FEUILLET, N. 2004. Inflation rate of the Colli Albani volcanic complex retrieved by the Permanent Scatterers SAR interferometry technique. Geophysical Research Letters, 31, L12606, doi:10.1029/2004GL020253.

Serpelloni, E., Anzidei, M., Baldi, P., Casula, G., Galvani, A. 2005. Crustal Velocity and Strain-Rate fields in Italy and Surrounding Regions: New Results From the Analysis of 
Permanent and Non-Permanent GPS Networks. Geophysical Journal International, 161, 861880.

StrüVer G., 1876, Studi sui minerali del Lazio. Parte I, Rendicontazione Accademia Nazionale dei Lincei, Memorie. Scenze Matematiche Fisiche Naturali, 3, 205-224;

TRIGILA, R. (ED) 1995. The volcano of the Alban Hills. Tipografia SGS, Rome, 283 pages.

Tuccimei, P., Giordano, G., Tedeschi, M., 2006. $\mathrm{CO}_{2}$ release variations during the last 2000 years at the Colli Albani volcano (Roma, Italy) from speleothems studies. Earth and Planetary Science Letters, 243, 449-462.

Villa, I.M., CAlanchi, N., Dinelli, E., LuCChini, F., 1999 Age and evolution of the Albano crater lake (Roman Volcanic Province). Acta Vulcanologica, 11, 305-310.

WASHINGTON, H.S., 1920. Italite, a new leucite rock. American Journal of Science, 50, 33-47.

WWw.INGV.IT (2006). INGV-DPC Progetto V3_1 Colli Albani. Responsabili Paolo Papale, INGVSezione di Pisa, Stefano Gresta, Università di Catania. Coordinatori Piergiorgio Scarlato, INGV-Sezione Roma 1, Mario Gaeta, Università degli Studi di Roma “La Sapienza”.

\section{Figure caption}

Fig. 1 a) The Colli Albani volcano (Central Italy). Ciampino Plain, AL= Albano Lake, NL=Nemi Lake; ALBA= GPS station at Albano; INGR= GPS station at INGV;GRA=highway encircling Rome are reported in the map; b) panoramic view of the Albano lake from the Astronomical Vatican Observatory (AVO) located in the Pope residence at Castelgandolfo.

Fig. 2 a) Historical topographic and bathymetric map of the Albano maar, dated back to 1930, based on surveys of the Italian Istituto Geografico Militare (performed between 1873 and 1940). b) Bathymetric map from multibeam data merged with topographic data of the aerial Lidar survey (Baiocchi et al. 2006; Baiocchi et al. 2007). A,B,C,D,E are the position of the main craters inferred from sub aerial and submerged surface morphology (sub aerial topography from aerial photo). RT=Roman Tunnel drain; RH=Roman Harbour; VM=Villaggio delle Macine of the Bronze Age (for details see also figs. 7c,d and e).

Fig. 3 a) 3-D surface of the lake floor from multibeam data (vertical exaggeration 8x). FS I, II and III are shown; b) multibeam images of the four past submerged coastlines (CL1 to CL4), inferred from notches located between -20 and $-41 \mathrm{~m}$ below the present lake surface. They mark the lake level standings at lower elevations between 7.1 and 4.5 ka B.P., in agreement 
with independent observations described in Villa et al. (1999). Past coastlines are particularly evident along the northern side of the crater, which is covered by soft sediments which preserved their morphology.

Fig. 4 a) The slides in the lake basin revealed by the multibeam bathymetry. For further details see also Bozzano et al. (2009). b) A particular of the northern side of the basin which shows Flat Surfaces (FSI, FSII and FSIII), submerged coastlines (CL) and slides (S), all marking the inner flank of the crater; c) a 3-D view of the same sector of the basin as shown in B. RT=Roman Tunnel drain; RH=Roman Harbour; VM=Villaggio delle Macine of the Bronze Age.

Fig. 5 Cartoon with a tentative 3-D reconstruction of the lake level changes (white dotted line marks the lake shore) since the end of the main volcanic activity: a) the craters before the lake formation (age $70 \mathrm{ka}$ ); b) the early Albano lake (age <70ka); c) lake level standings between -20 and -41 m (this paper and stratigraphic data from Chondrogianni et al. 1996); d) lake outflow around 3800 B.C.E.; e) lake level in 1600 yr B.C.E. (archaeological data of the Bronze Age Villaggio delle Macine); f) lake outflow in 398 B.C.E. (historical report from Tito Livius in Historia Romae, book V, 15:4-7); g) hypothetical lake level decrease after the 398 B.C.E. outflow; h) lake level in 1870-1940 (maps from the Italian Istituto Geografico Militare); i) lake level during the 1960 Rome Olympic games.

Fig.6 Lake level changes curve based on geological, historical and instrumental data (Capelli Mazza 2005). Lake level data are collected since 1940 by the limnographic station (LS) located at the entrance of the Roman tunnel drain (RT in Fig.2b, 4a) (see graph in the bottom right box). The LS dried at the end of 1990 due to the rapid decreasing of the lake level, after a period (1987-1990) of increasing seismicity (see also Fig.7g). The maximum estimated amplitude of the lake level changes is more than $100 \mathrm{~m}$, since historical times. The horizontal dotted line at zero elevation, is the reference lake level at 2005 (MB survey).

Fig.7 Evidences of the lake level changes. a) The concrete tripod installations built in the water for the rowing competitions during the Rome 1960 Olympic Games (photo courtesy of Enrico Tonali); b) the same structures are nowadays completely dried and show about 3.60m lake level decrease and about $60-80 \mathrm{~m}$ of shore retreat; c) the remnants of the pile-dwellings (evidenced by white rectangles) of the Bronze Age Villaggio delle Macine; d) the pier of the roman harbour at the foot of the II century C.E: villa (the photo shows a particular of the moorings), is dried as well as the Roman tunnel drain e) and f) excavated in 398 B.C.E. and 
the limographic station g) placed at its entrance, active in the time span 1950-1997 (in the box a particular of the graduate scale of the water level dated back at 1954, is shown). The latter witness the dramatic lake level decrease started at the beginning of 1990. All these indicators provide a precise measure of the intervening lake level variations and the change in the environment affecting the lake basin. 


\section{FIGURES}

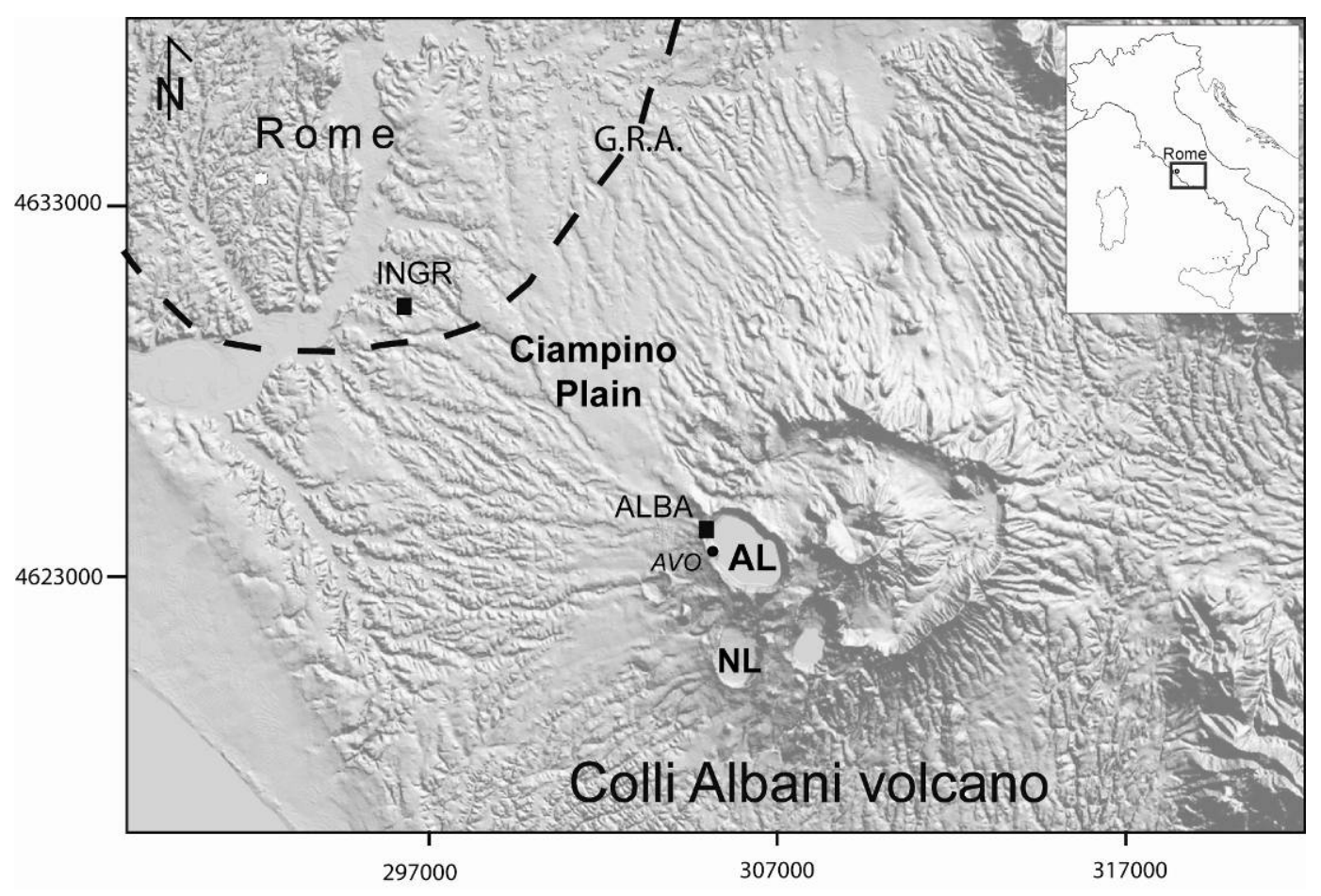

Fig.1a

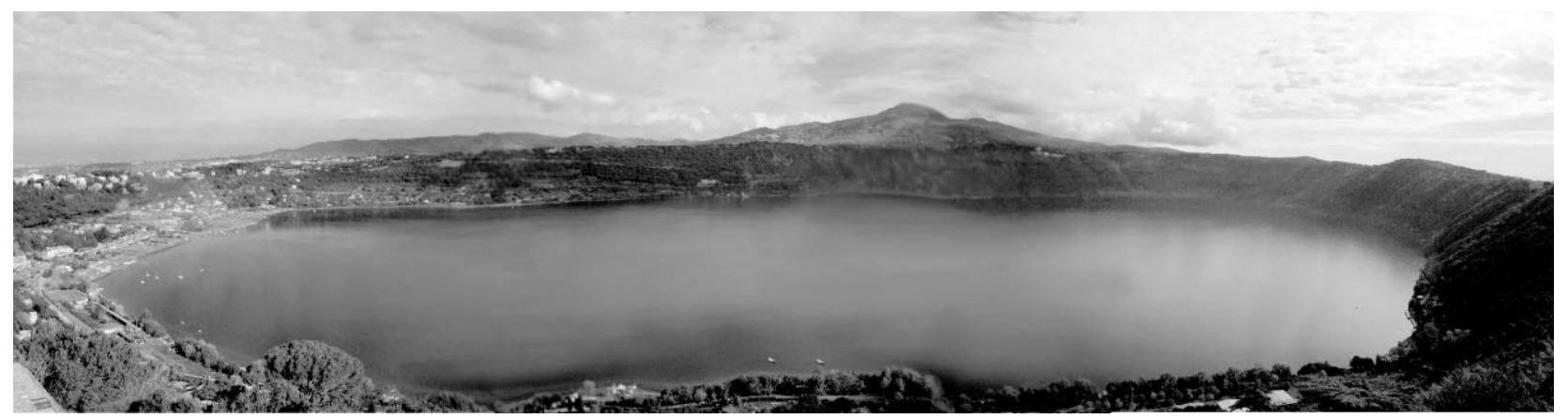

Fig.1b 


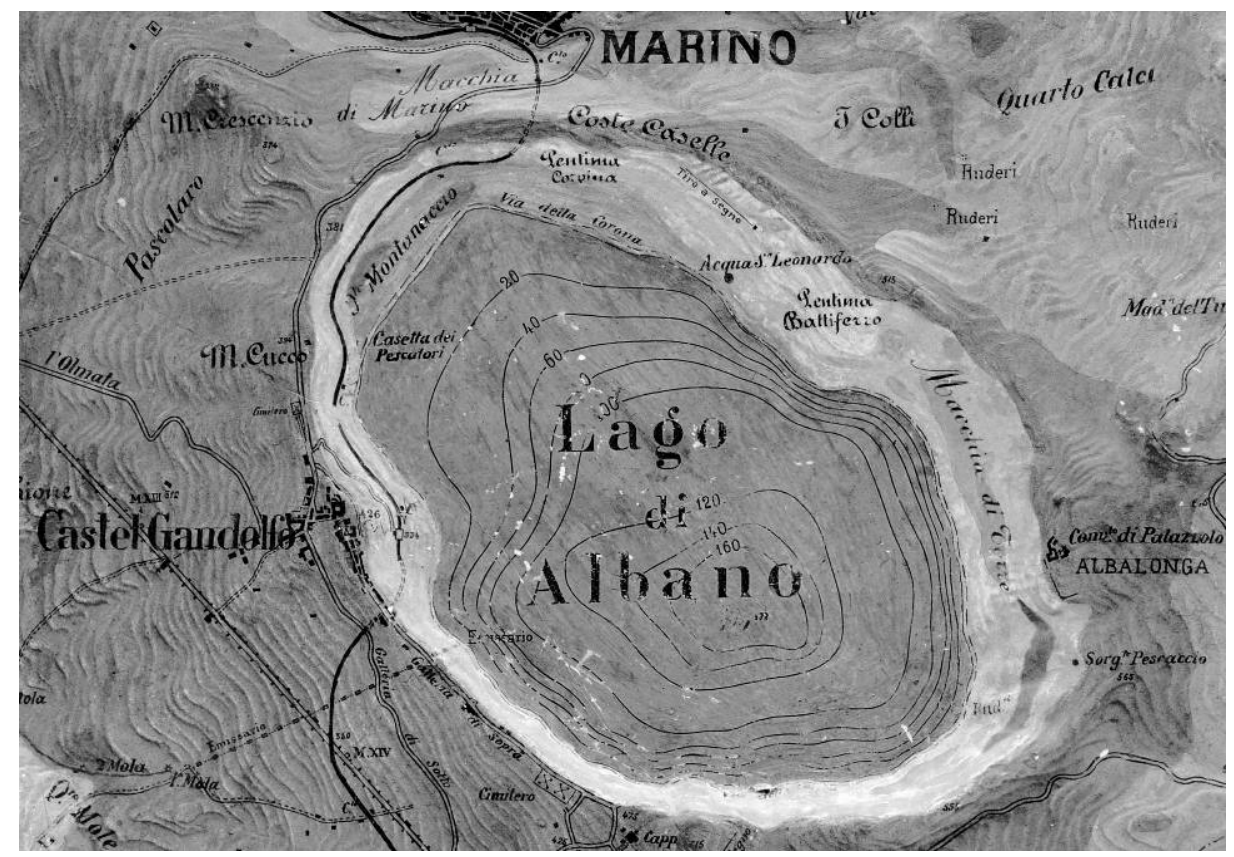

Fig.2a

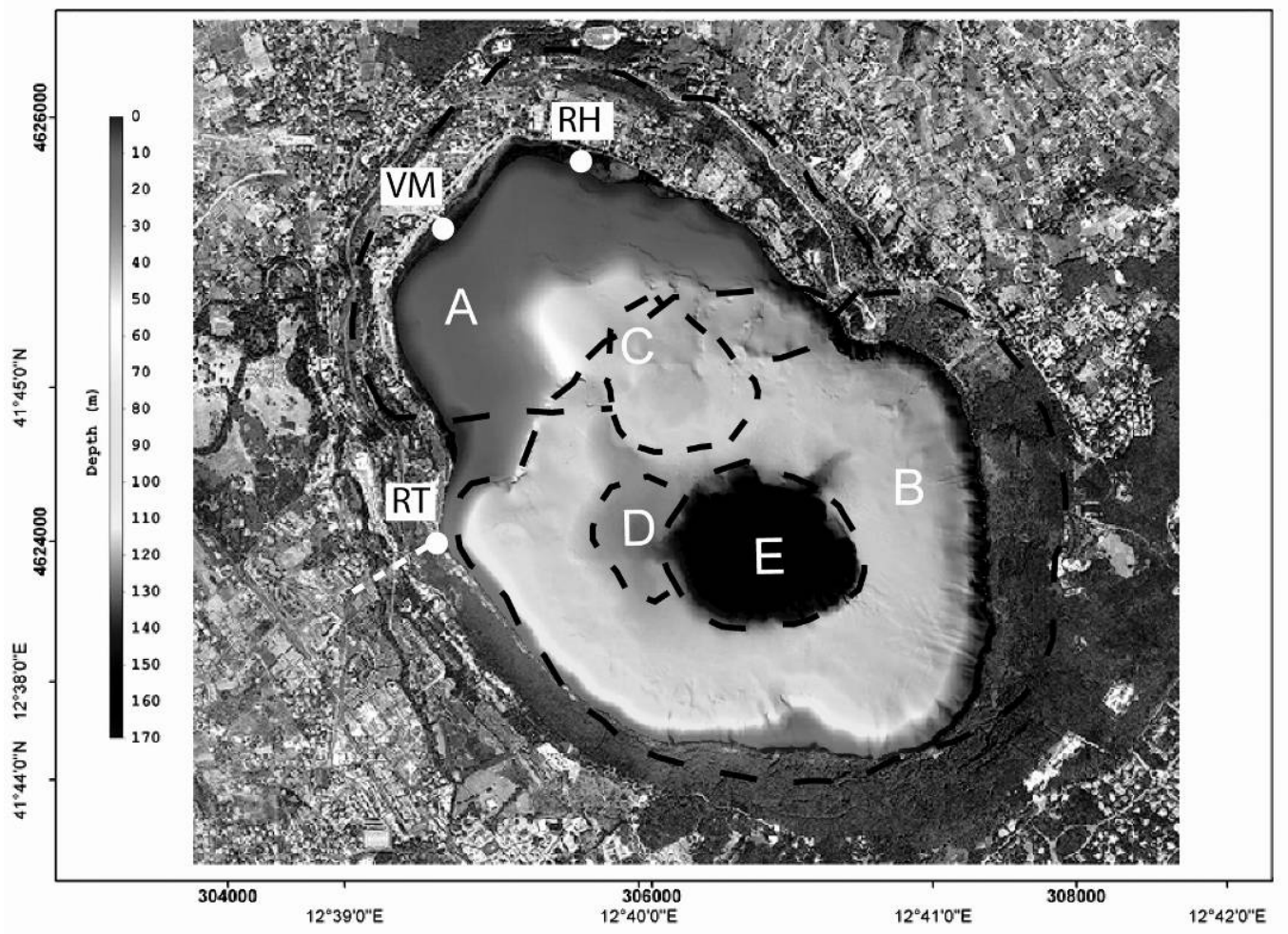

Fig.2b 


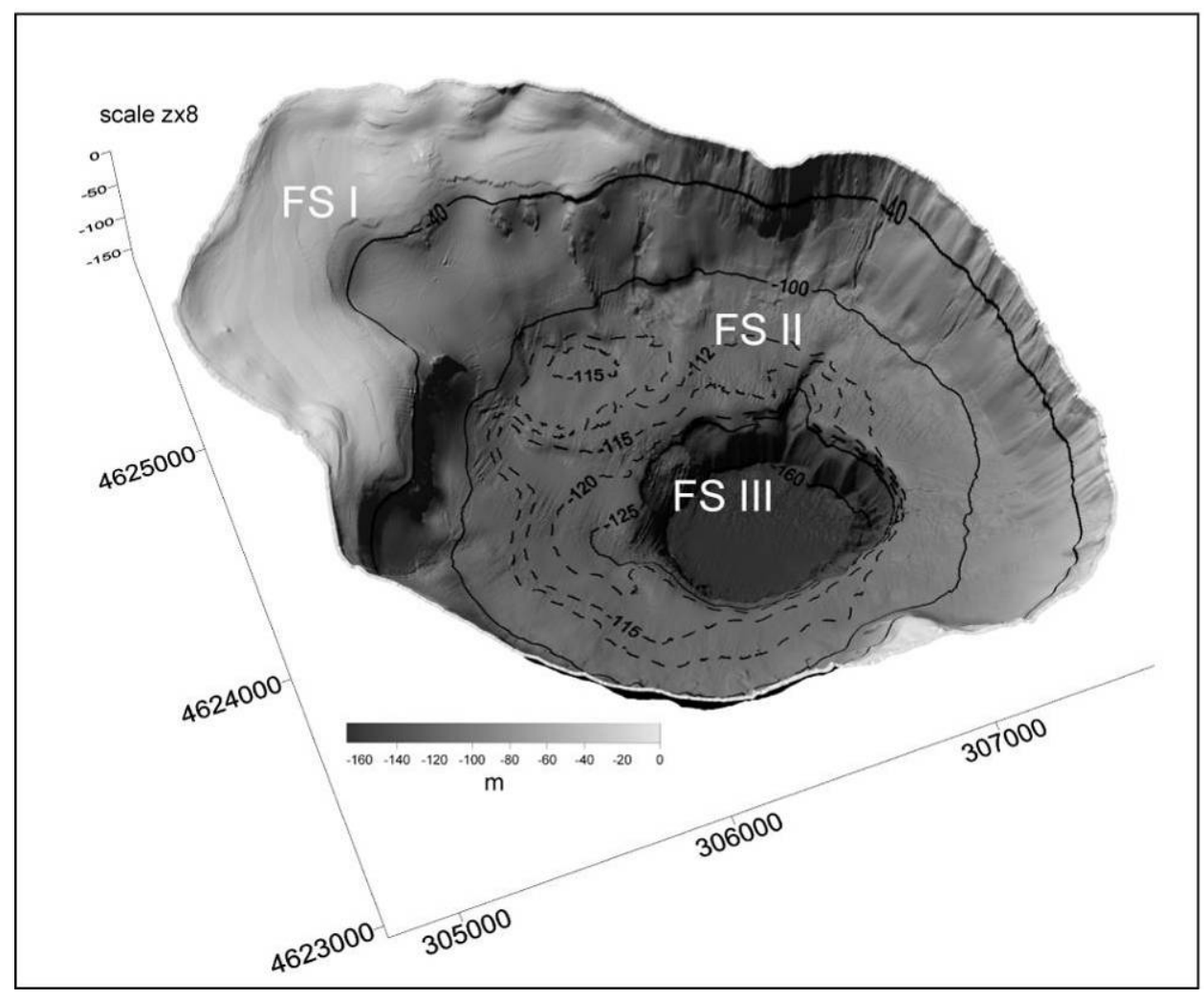

Fig.3a

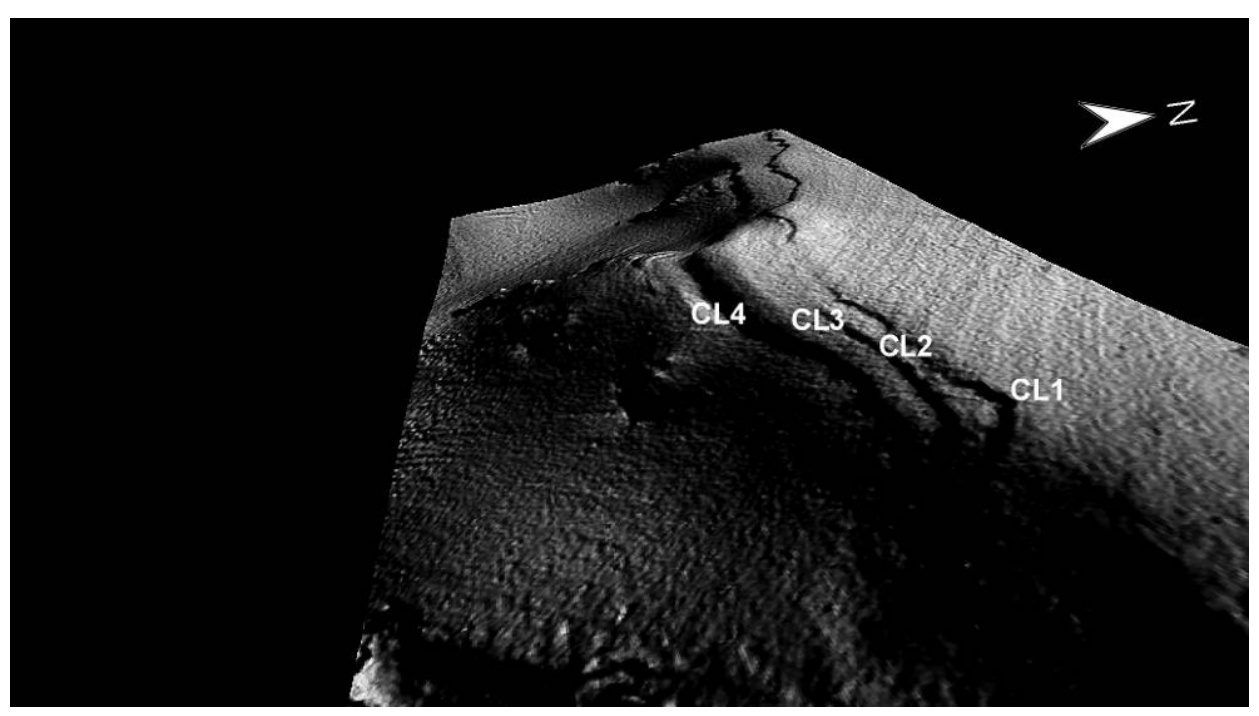

Fig. 3b 


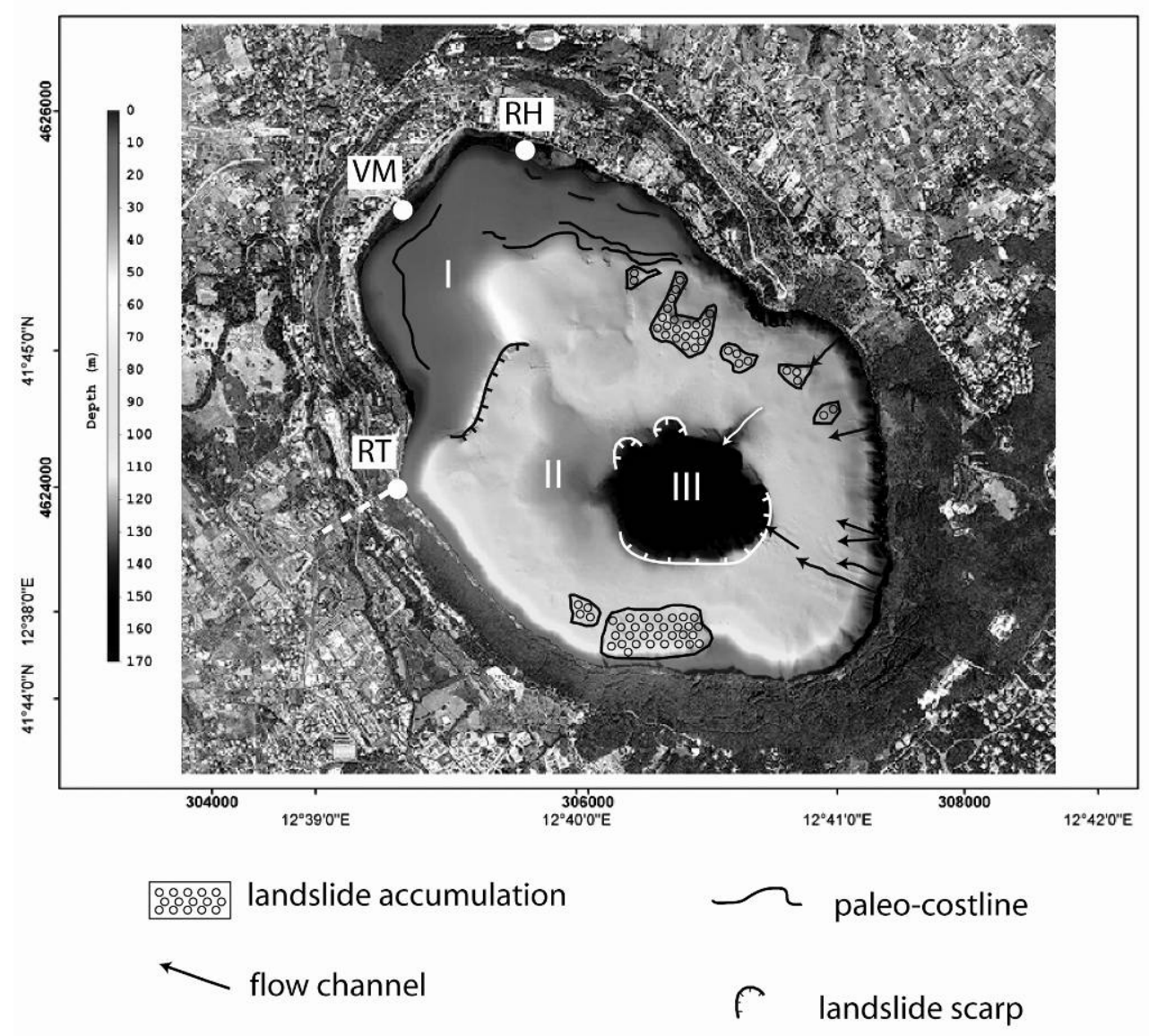

Fig.4a

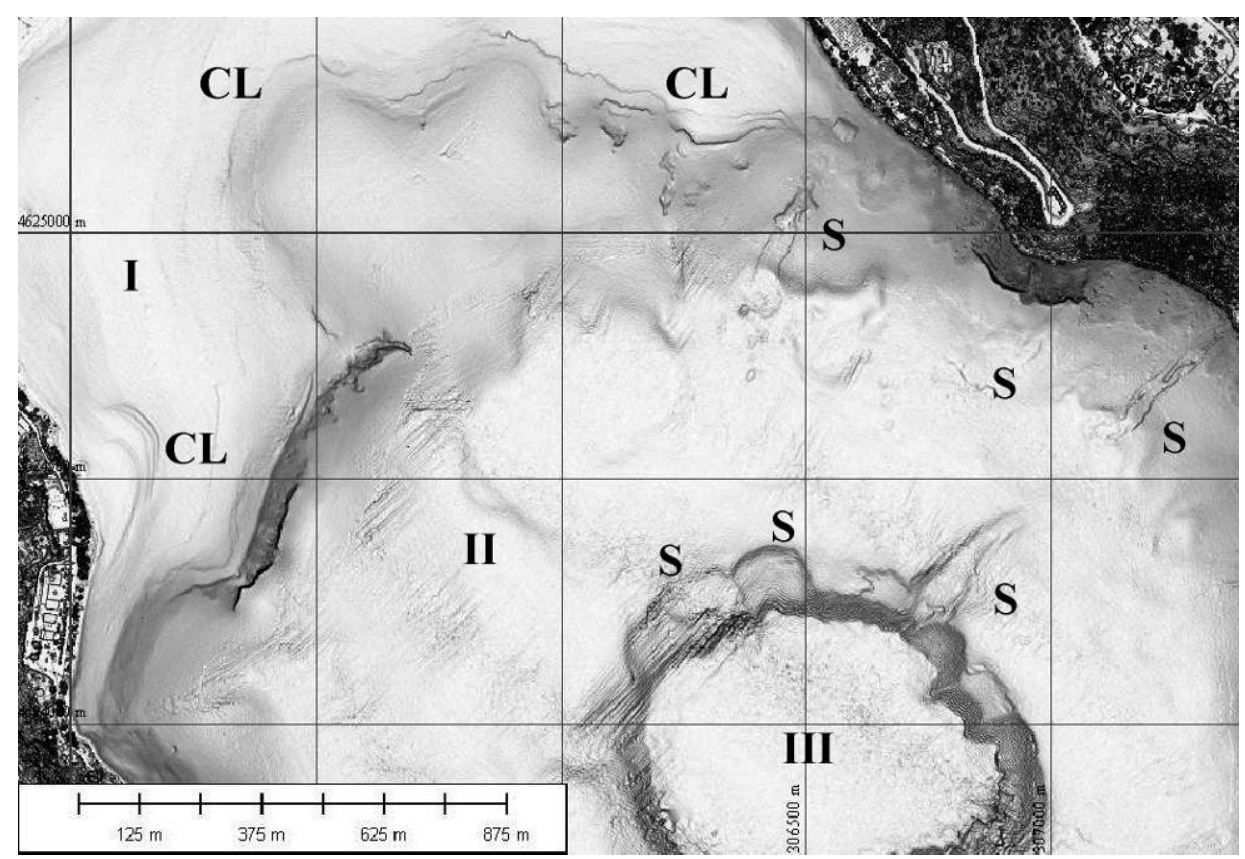

Fig.4b 


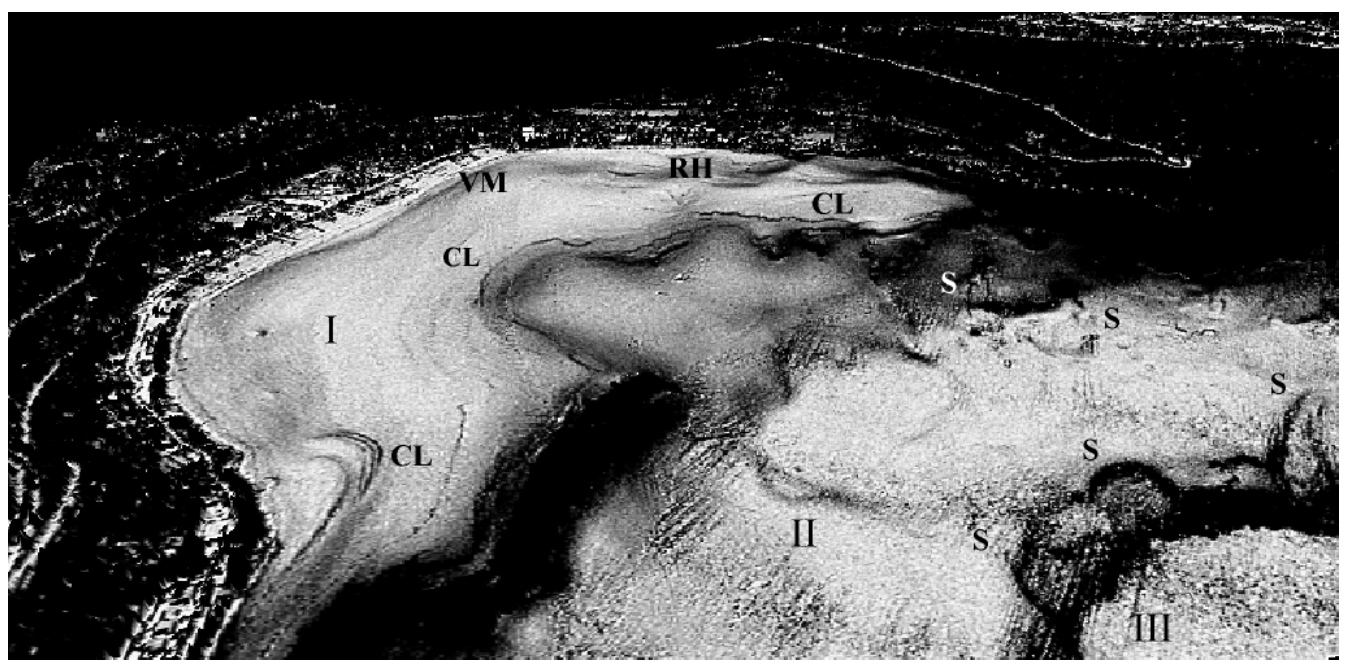

Fig. 4c

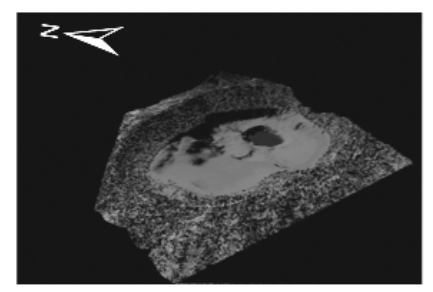

a

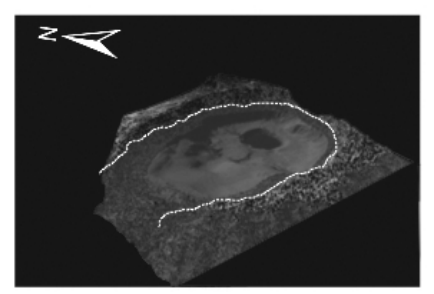

d

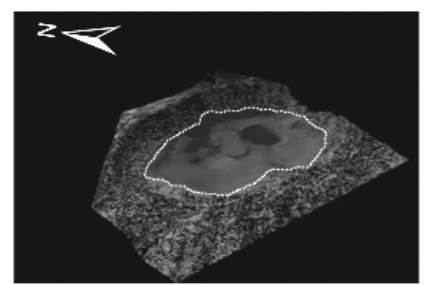

g
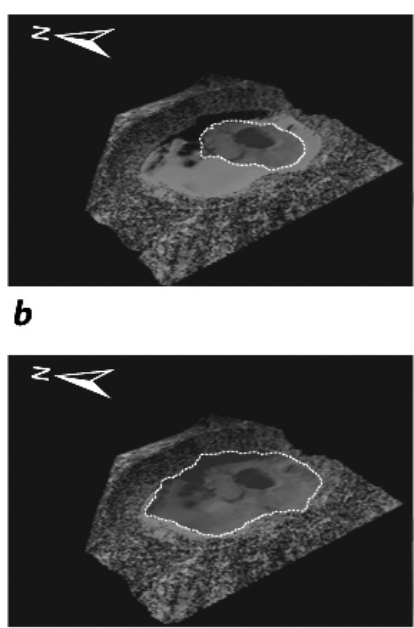

e

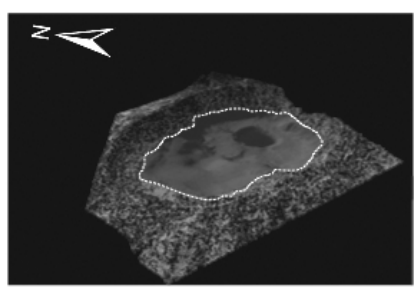

$\boldsymbol{h}$
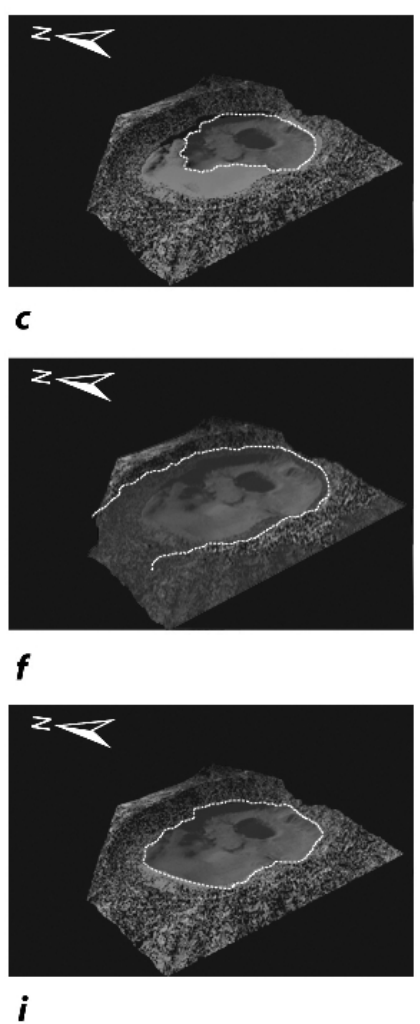

Fig.5 


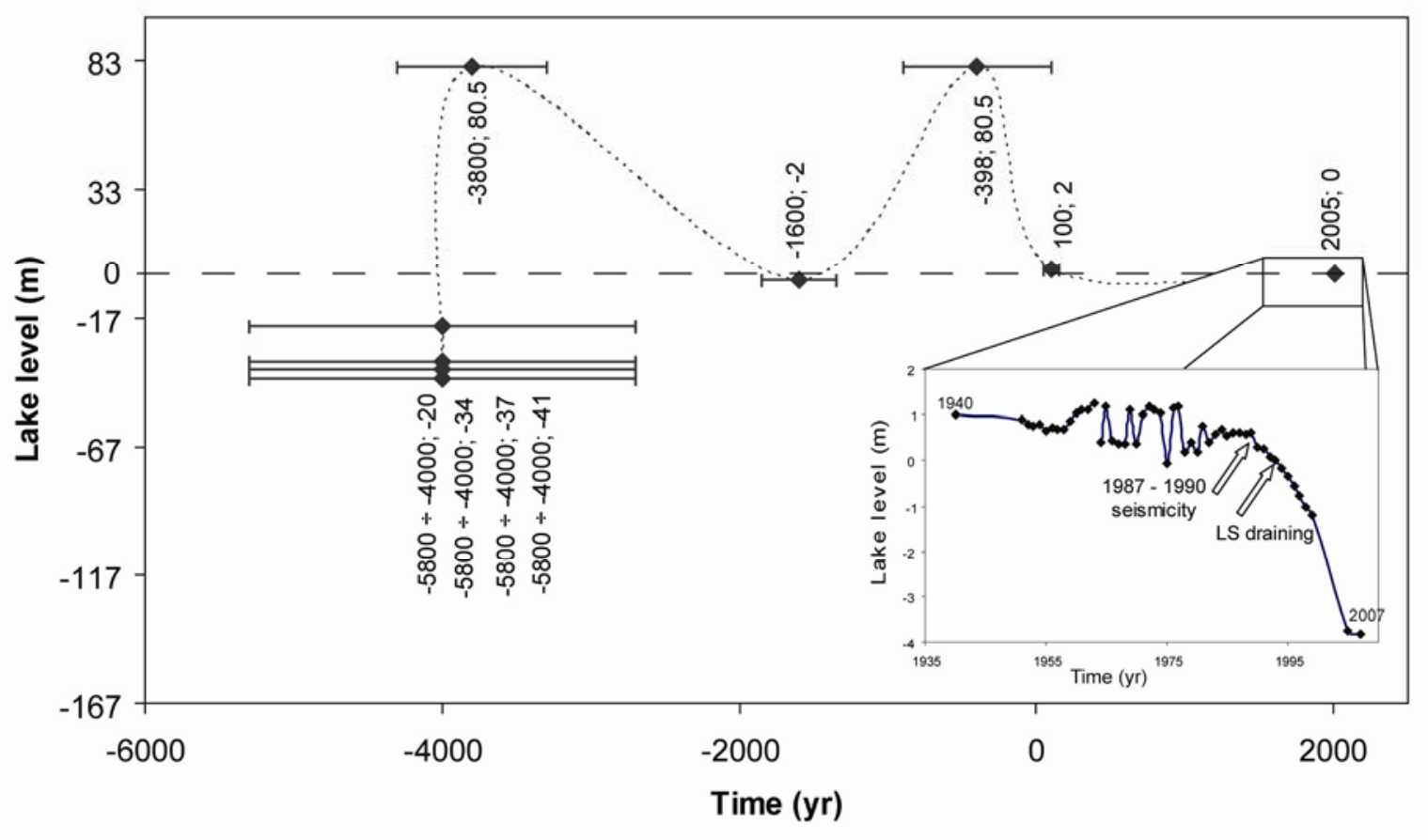

Fig.6

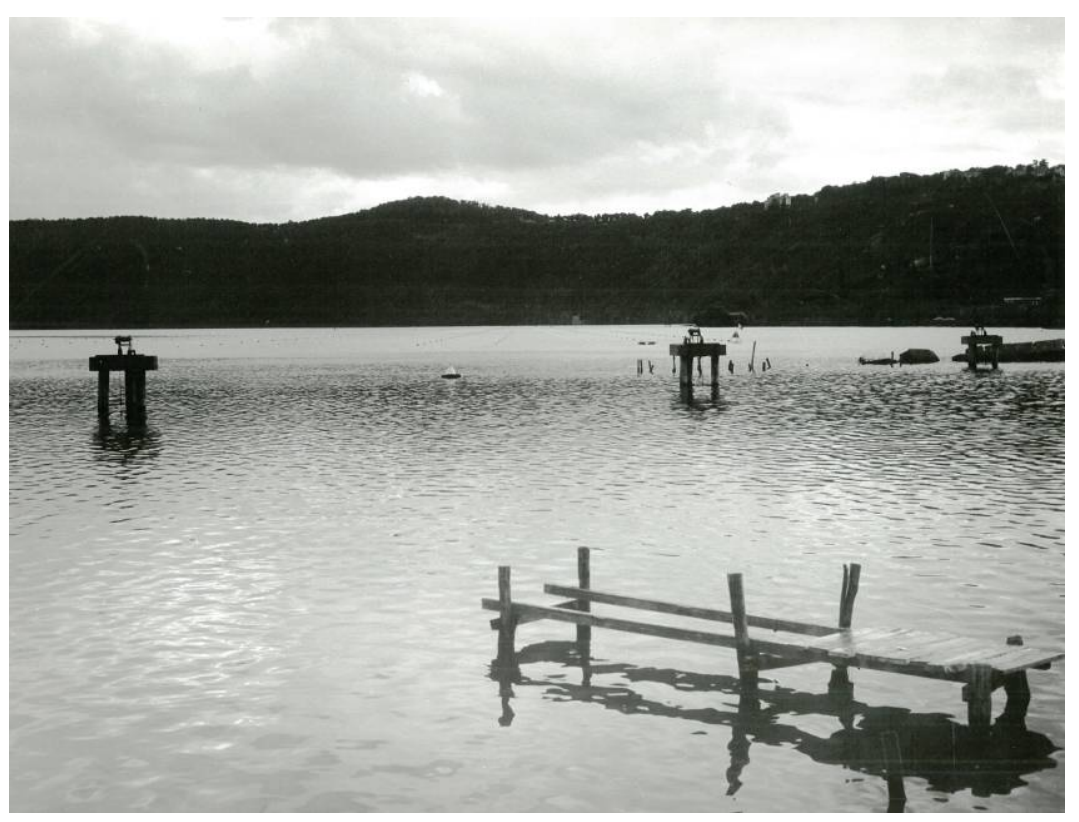

Fig. 7a 


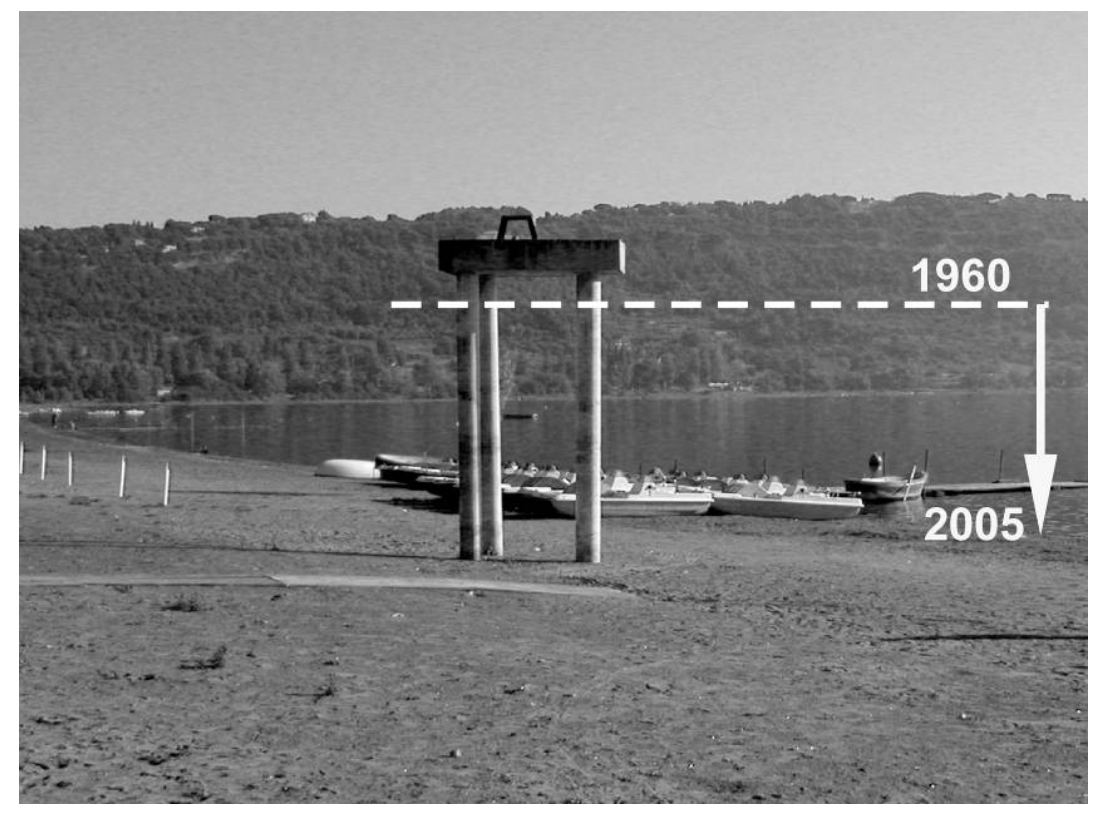

Fig.7b

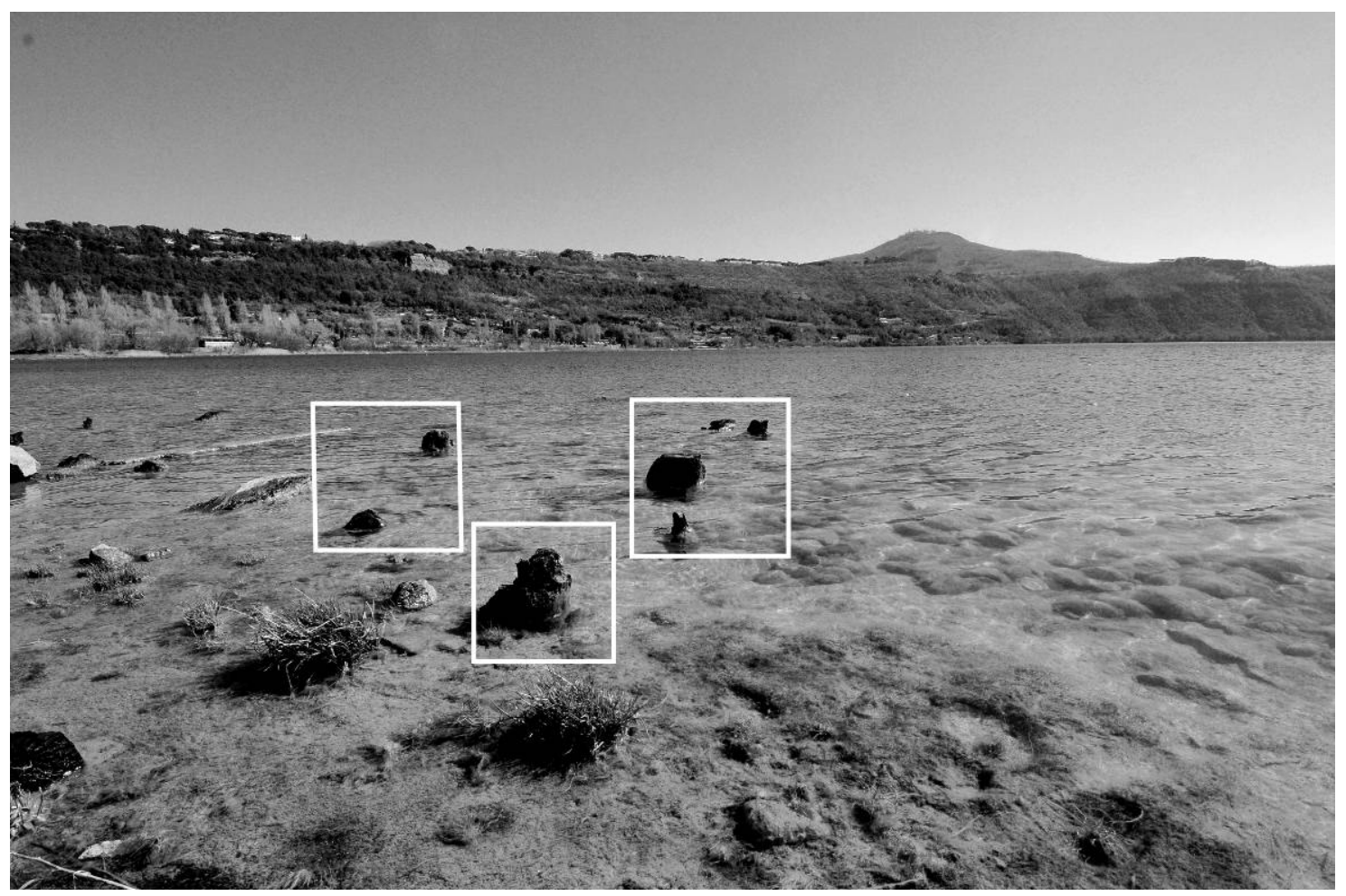

Fig.7c 


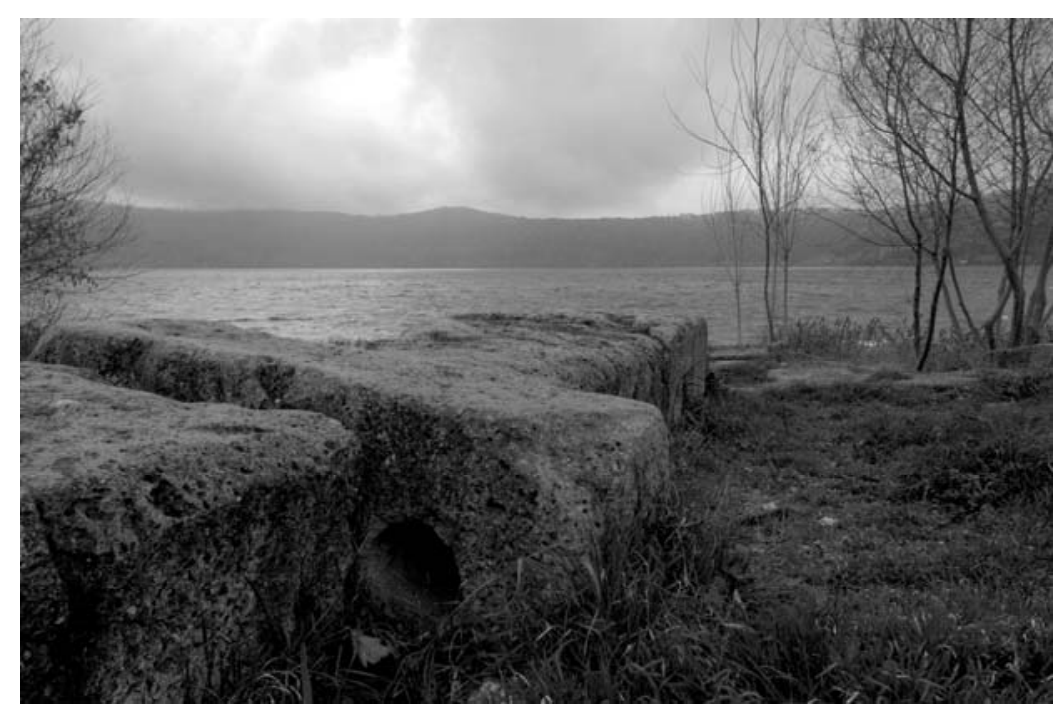

Fig.7d

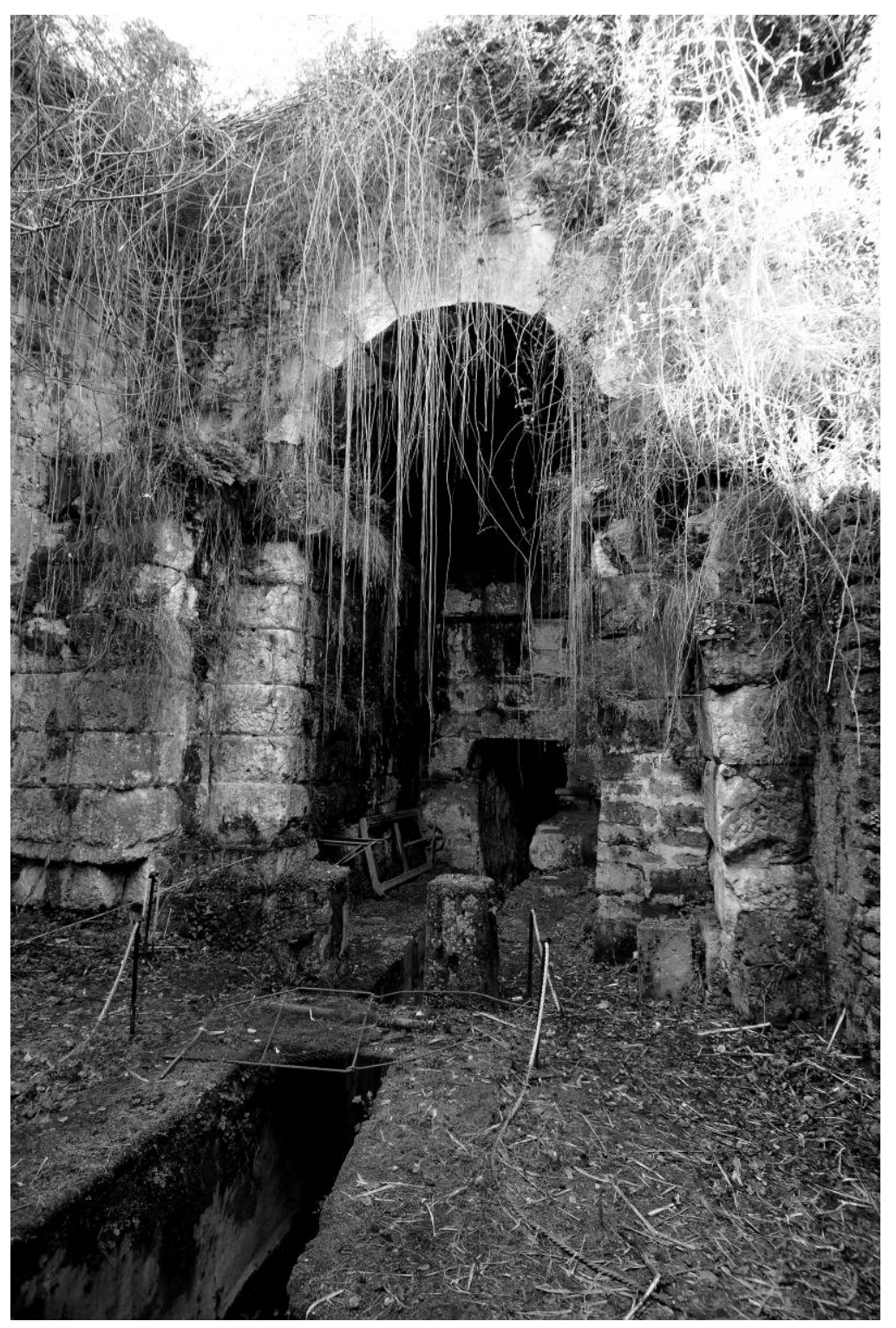

Fig.7e 


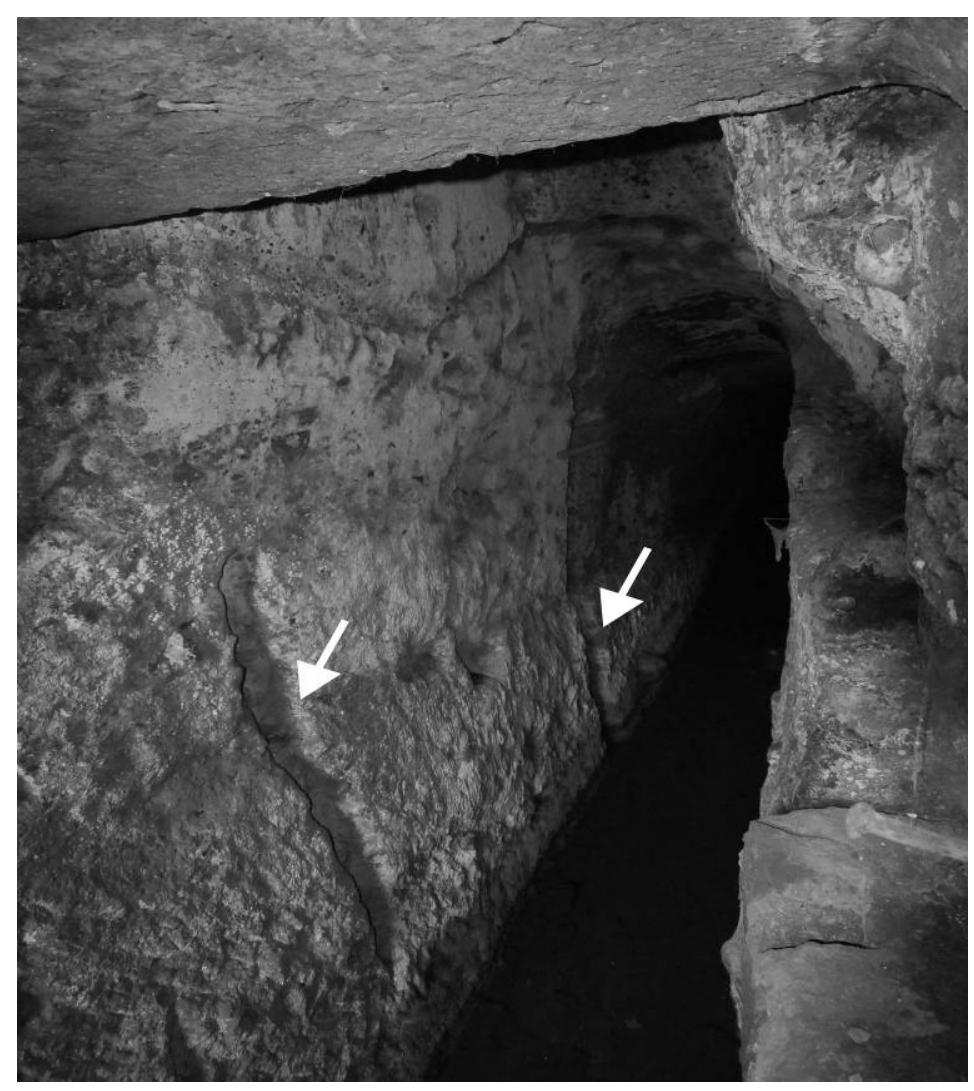

Fig.7f

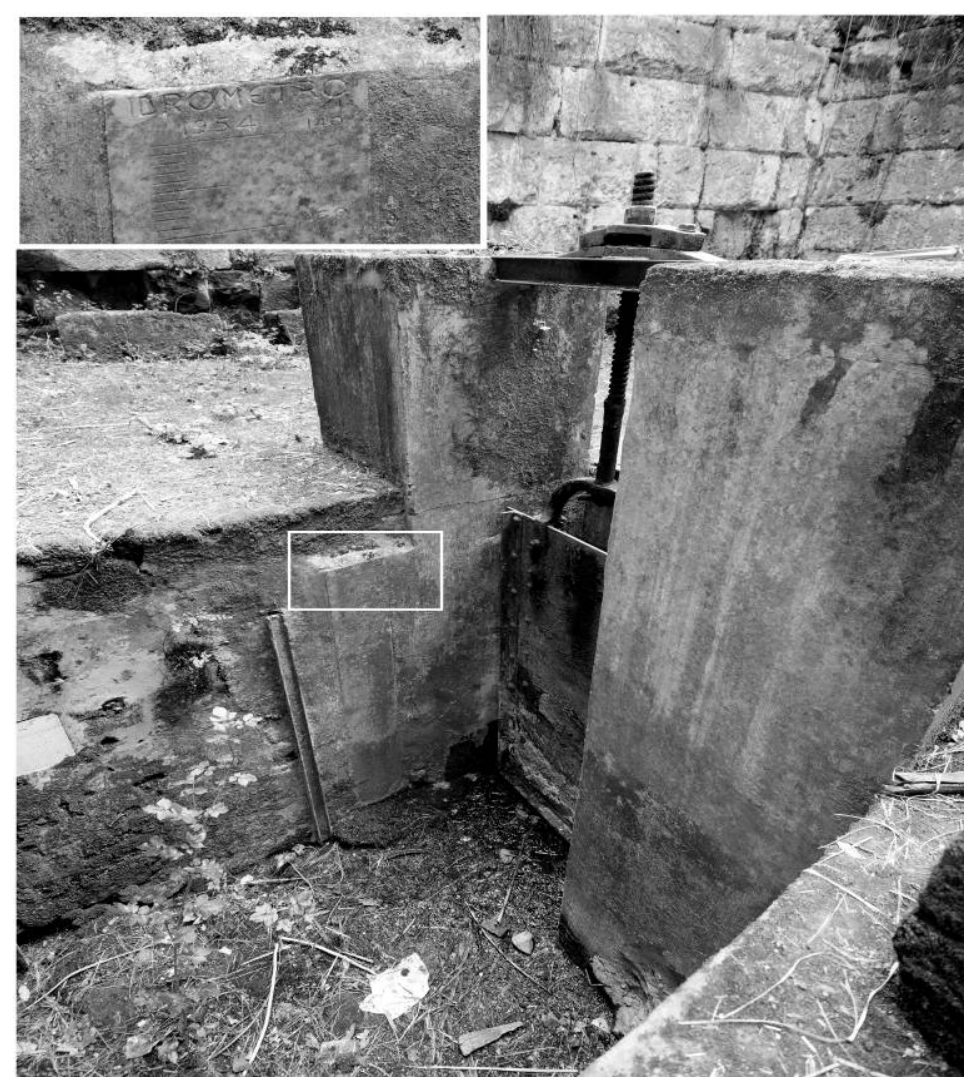

Fig. $7 g$ 